\title{
OCCURRENCE OF BARRED KNIFEJAW, OPLEGNATHUS FASCIATUS (ACTINOPTERYGII: PERCIFORMES: OPLEGNATHIDAE), IN MALTA (CENTRAL MEDITERRANEAN) WITH A DISCUSSION ON POSSIBLE MODES OF ENTRY
}

\author{
Patrick J. SCHEMBRI ${ }^{1 *}$, Pascaline BODILIS ${ }^{2}$, Julian EVANS ${ }^{1}$, and Patrice FRANCOUR ${ }^{2}$ \\ ${ }^{1}$ Department of Biology, University of Malta, Msida MSD2080, Malta \\ ${ }^{2}$ University of Nice-Sophia Antipolis, ECOMERS, Sciences Faculty, Parc Valrose, France

\begin{abstract}
Schembri P.J., Bodilis P., Evans J., Francour P. 2010. Occurrence of barred knifejaw, Oplegnathus fasciatus (Actinopterygii: Perciformes: Oplegnathidae), in Malta (Central Mediterranean) with a discussion on possible modes of entry. Acta Ichthyol. Piscat. 40 (2): 101-104.
\end{abstract}

\begin{abstract}
The barred knifejaw, Oplegnathus fasciatus (Temminck et Schlegel, 1844), a species native to the North Western and Eastern Central Pacific, is recorded from the central Mediterranean for the first time. Two individuals were photographed within a month of each other in Grand Harbour and in Marsamxett Harbour, Malta. It seems likely that the fish were introduced by shipping and different scenarios how this may have happened are discussed.
\end{abstract}

Keywords: barred knifejaw, non-indigenous species, shipping, Mediterranean, Maltese Islands

The Mediterranean marine biota is well known for its complement of non-indigenous species (NIS) the bulk of which originate from the adjacent North East Atlantic or the Red Sea, to which the Mediterranean is connected via the Strait of Gibraltar and the Suez Canal, respectively (Zenetos et al. 2005, Galil 2009). Such NIS enter the Mediterranean either due to a natural range extension or due to direct or indirect transport by humans. To date, some 127 nonindigenous fish have been recorded from the Mediterranean (Golani et al. 2002, Ben Rais Lasram and Mouillot 2009). As with other NIS, almost all are species that occur in adjacent seas, however, a few have areas of distribution far afield from either the NE Atlantic or the Red Sea. Such species include honeycomb grouper, Epinephelus merra Bloch, 1793, from the Indian/Pacific Ocean (Patrick Lelong, Paul Ricard Oceanographic Institute, personal communication); dwarf flathead, Elates ransonnetti (Steindachner, 1876), from the Central Pacific (Mastrototaro et al. 2007); muzzled blenny, Omobranchus punctatus (Valenciennes, 1836), from the Indo-Pacific outside the Red Sea; the circumtropical antenna codlet, Bregmaceros atlanticus Goode et Bean, 1886; and chameleon goby, Tridentiger trigonocephalus (Gill, 1859) from the West Pacific (Goren et al. 2009). It could therefore be assumed that in such cases human transport is the most probable mode of introduction and the agents that have usually been implicated are aquaculture, the aquarium trade, and shipping (Golani et al. 2002, Galil 2009, Goren et al. 2009).

Here we report an extreme case of translocation from one sea to another. In November and December of 2009, two specimens of the barred knifejaw, Oplegnathus fasciatus (Temminck et Schlegel, 1844), were photographed in Malta. The first individual was caught from the shore using a rod and line by angler John Attard on the morning of 22 November 2009 at the Valletta Waterfront within the Grand Harbour, Malta from a depth of ca. $11 \mathrm{~m}$ during an amateur fishing marathon in aid of a charitable institution. The fish was landed, photographed (Fig. 1), and released back to the sea. It was not measured but the angler estimated its size as $12-14 \mathrm{~cm}$ in length and 6-7 $\mathrm{cm}$ in width (Reno Tonna, Malta Fishing Forum, personal communication). The second specimen was photographed on 25 December 2009 swimming at a depth of $12 \mathrm{~m}$ close to HMS MAORI - a wartime wreck which is a popular diving site located close to the mouth of Marsamxett Harbour, Malta. The fish was not captured but its length was estimated to be $20 \mathrm{~cm}$ (Catherine Gras, personal communication). A detailed comparison of the available photographs was made and apart from the size difference between the two specimens (which is not very reliable given that neither specimen was actually measured) differences in the width of the dark border of the tail and of the second dorsal fin of the two were apparent. Therefore, it was concluded that the two photographs are of different individuals and not of the same fish that had roamed between the Valletta Waterfront and the wreck of the HMS MAORI; such movement is entirely possible given that the swimming distance between these two sites is ca. $2.4 \mathrm{~km}$. Oplegnathus fasciatus is reported to live close to the bottom on coastal rocky reefs at depths of 1-10 m, to feed on

\footnotetext{
${ }^{*}$ Correspondence: Prof. Patrick J. Schembri, Department of Biology, University of Malta, Msida MSD2080, Malta; phone: +356 2340 2789, fax: +356 2132 3781; e-mail: patrick.j.schembri@um.edu.mt
} 
small benthic invertebrates, and to reach a maximum size of about $80 \mathrm{~cm}$ TL (Froese and Pauly 2010). The area of distribution of $O$. fasciatus is the region of Korea, Japan, Taiwan, and Hawaii in the North West and Eastern Central Pacific (Froese and Pauly 2010) and it has not been previously recorded from the Mediterranean, or from the Atlantic or the Red Sea/Indian Ocean, that is, anywhere between Malta and its native area of distribution. Hence, range extension is not a realistic possibility and transport due to human activity is the most likely explanation of the present records.

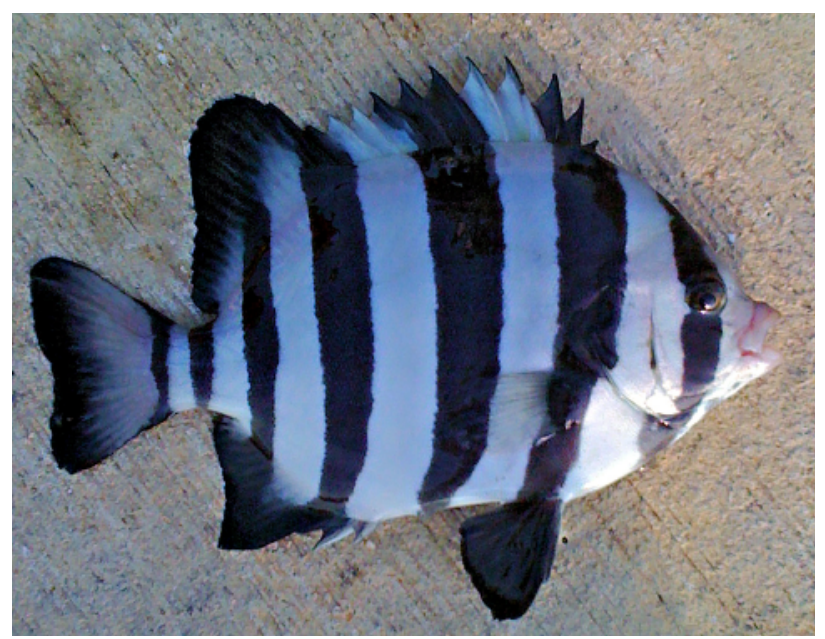

Fig. 1. Photograph of the specimen of Oplegnathus fasciatus captured from the Valletta Waterfront, Grand Harbour, Malta by John Attard on 22 November 2009; The fish was ca. $13 \mathrm{~cm}$ long (Photograph ${ }^{\circledR}$ John Attard, 2009)

In Korea, this species is an important food fish, and the fry is cultured in hatcheries and released into the sea to sustain the natural populations (Kim et al. 2008). We made extensive enquiries with Maltese fish farmers and researchers on fin-fish aquaculture, as well as with the Government of Malta's National Aquaculture Centre. However, this species has never been imported for either commercial or experimental aquaculture in Malta. We also made enquiries with the Environment Protection Directorate of the Malta Environment and Planning Authority, which is the Maltese agency responsible for regulating importation of species covered by legislation. It resulted that there are no records that any application to import species of Oplegnathus into Malta has ever been made. One problem is that whereas prior to Malta's accession to the European Union on 01 May 2004 practically any importation of species not native to Malta required a permit, following accession, permits for entry of nonnative species from EU Member States were no longer required. We therefore contacted all the major importers of aquarium fishes in Malta and asked if they have ever imported Oplegnathus fasciatus or any other species of 'Knifejaw'; we obtained negative results. In addition, this species is not listed on the stock list of the main aquarium-fish sellers in the EU (Benoit Tchepidjian, Union for the Development of Aquaculture in French Polynesia, personal communication) and this species is not known to be farmed in the EU (Emmanuel Briquet, Provence FishFarming, personal communication).

Barring exceptional circumstances, it seems that the most likely vector for entry of Oplegnathus fasciatus into Malta is shipping. The present case concerns at least two sub-adult fish that seem to have been 'translocated' from the North West Pacific to the Mediterranean in good condition, then 'released' into the wild to survive for at least 33 days (the period of time between the two records). The literature contains numerous references to shipping as a vector for long-distance translocations of fish similar to the present case, and most authors have suggested that the animals travelled in ballast water (e.g., Mastrototaro et al. 2007, Goren et al. 2009 for the Mediterranean; see also Anonymous 1996).

There are several possible scenarios how fish may translocate through shipping from a far distant source port to a destination port: (1) Sub-adult and/or adult fish associate with the hulls of large ships, utilizing habitats formed by fouling species; (2) Sub-adult and/or adult fish enter the ship at the source port and are discharged at the destination port; (3) Larvae enter the ship at the source port, continue developing during the journey and are discharged as advanced larvae or young juveniles at the destination port, then continue development in the wild; (4) Larvae enter the ship at the source port, develop into sexually mature adults in the ship, spawn while still in the ship, then eggs or larvae are discharged at the destination port and continue development in the wild. Within a ship, eggs, larvae or adults may travel in ballast tanks or in any other seawater-containing space that provides all the fish's requirements during the journey (Gerhardinger et al. 2006, Coutts and Dodgshun 2007).

Because of the size and the known behaviour of $O$. fasciatus, we exclude scenario 1. Most modern ships pump water into ballast tanks using centrifugal pumps protected by screens that may allow eggs, larvae or very small fish through but not anything much larger than $5 \mathrm{~mm}$ (the mesh size quoted by Coutts and Dodgshun 2007). Ballast tanks are emptied by pumps again protected by screens which limit the size of organism that can pass from a ballast tank to the outside. Moreover, any organism small enough to pass through the protective screens will need to survive the very high forces and the extreme turbulence generated by the pumps. While planktonic eggs and larvae may be able to do this, it is unlikely that larger organisms will survive passage through the pumps undamaged. Scenario 2 is therefore unlikely to explain the present case.

According to Koh and Kim (1992), the eggs of Oplegnathus fasciatus hatch within $36 \mathrm{~h}$ from laying (at ca. $22^{\circ} \mathrm{C}$ ) and postlarvae of TL $15.51 \mathrm{~mm}$ are formed 35 days from hatching. Ships take some three weeks to travel from the remote Pacific (Australia) to the central Mediterranean (Flagella et al. 2006). This is long enough for eggs or young larvae taken into ballast tanks to develop into late larvae that may then be pumped out at the destination port to continue development. Scenario 3 is there- 
fore possible but requires a period of post-larval development in the destination port. This is also possible, however, given the very conspicuous coloration of the fish and that there are no fish with a similar colour pattern in the central Mediterranean, it is reasonable to expect that a juvenile would have been detected before it reached the ca. $13 \mathrm{~cm}$ TL of the Valetta Waterfront specimen. Scenario 4 is also possible but even if a breeding population of fish can survive in a ballast tank, post-larval development in the destination port is still necessary, with the same considerations as for Scenario 3. In addition, the IMO (International Maritime Organisation, Anonymous 2010) has advised that all vessels have to exchange their ballast waters on the open sea before arriving in a new harbour. Because this technique is not sufficient to destroy all invasive organisms, chemical or physical treatments can be used inside ballast tanks (Gregg et al. 2009). Such treatments are normally effective on marine organisms, even microscopic ones. As a consequence, only resistant forms such as dinoflagellate cysts would resist the treatment. Therefore, transport via ballast water may explain the present case, but only given rather particular circumstances.

However, another possibility exists. Most medium- to large-sized ships do not pump seawater directly from the sea but from a chamber know as a 'sea chest' which opens to the outside on the ship's hull below the waterline. The characteristics of sea chests from the perspective of marine bioinvasions have been discussed by Coutts and Dodgshun (2007). Large ships may have more than one sea chest, each of which may hold several cubic metres of seawater in constant exchange with the sea and which is only emptied when the ship is dry-docked. In effect, sea chests act like seawater aquaria and provide a means of transport for larger-sized, non-fouling marine species that does not involve passage through a pump. Indeed Coutts and Dodgshun (2007) found 150 different organisms in 53 sea chests from 42 vessels operating in New Zealand in 2000-2004, including four species of fish.

The openings of sea chests are normally protected by a grille or a perforated plate designed to prevent floating debris from entering the sea chest. Grille and perforation spacing varies greatly between vessels but will limit passage of large organisms. According to Coutts and Dodgshun (2007), the holes of perforated plates may be 15-25 $\mathrm{mm}$ in diameter and grille spaces may be 20-35 $\mathrm{mm}$ wide by up to $250 \mathrm{~mm}$ long. However, it is possible for a large fish to circumvent this obstacle. Should the perforated plate protecting entry to the sea chest become damaged or dislodged at sea, this will remain undetected until at least the first port of call, providing an opportunity for entry of large marine organisms that would not normally be able to access a sea chest. Additionally, on medium-sized vessels at least, the sea chest grille or perforated plate may become so heavily fouled that it reduces intake of water into the ship. In such cases, when in port, divers often remove the plate for cleaning on board and then replace it (Carmel Grech, Chief Engineer, Authority for
Transport in Malta, personal communication); in the interim period the sea chest is submerged and fully open to the sea permitting a free exchange of biota between the water in the sea chest and the external environment. In addition to the variety of factors that influence occupancy as described above, Coutts and Dogshun (2007) consider that even if a variety of treatment systems involving the release of toxic chemicals are currently available to prevent occurrence and survival of organisms within sea chests, they are relatively expensive and hardly efficient against mobile organisms.

Although we have no evidence as to the mode of transport of Oplegnathus fasciatus to the central Mediterranean, there does exist a low volume of direct ship traffic between the North West Pacific and Malta as well as a much higher volume on the same route but with multiple stops along the way (Keon Vella, Merchant Shipping Directorate, Authority for Transport in Malta, personal communication). There are also quite plausible ways in which fish of the size of the Oplegnathus fasciatus found in the Malta harbours could be transported from a source area thousands of kilometres away and be released into the wild in a good state of health. We therefore suggest that shipping, but not necessarily ballast water, has been the most probable transport agent in the present case. The analysis made here is applicable to other cases of long-distance translocations of large fish.

\section{ACKNOWLEDGEMENTS}

We thank Jonathan Cassar, Edwin Zammit, and Reno Tonna (Malta Fishing Forum http://maltafishingforum.com), and Catherine Gras and Doris Forum staff (http://doris.ffessm.fr/), for bringing the photographs of the fish to our attention and for providing information on the circumstances of the records; we also thank John Attard for kindly allowing us to reproduce his photograph of the specimen caught from the Valletta Waterfront. We are grateful to the numerous persons who helped us in the preparation of this paper by generously providing information: Dr Robert Vassallo Agius (National Aquaculture Centre, Malta), Prof Carmelo Agius (University of Malta), Matthew Grima Connell (Malta Environment and Planning Authority), Stephen Camilleri, Keon Vella and Carmel Grech (Authority for Transport in Malta), Robert Gandolfo (Sea PACA Cluster, France), Benoit Tchepidjian (Union for the Development of Aquaculture in French Polynesia), Emmanuel Briquet (Provence FishFarming, France), Dr Denis Coves (IFREMER Palavas, France), and Dr. Marc Taquet (IFREMER, French Polynesia).

\section{REFERENCES}

Anonymous 1996. Stemming the tide. Controlling introduction of non-indigenous species by ships' ballast water. National Research Council. Report of the Committee on Ships' Ballast Operations, Marine Board, Commission on Engineering and Technical Systems. National Academy Press, Washington DC, USA. 
Anonymous 2010. International Convention for the Control and Management of Ships' Ballast Water and Sediments. International Maritime Organisation. http://www.imo.org/conventions/mainframe.asp?topic_id=867.

Ben Rais Lasram F., Mouillot D. 2009. Increasing southern invasion enhances congruence between endemic and exotic Mediterranean fish fauna. Biological Invasion 11 (3): 697-711. DOI: 10.1007/s10530-008-9284-4.

Coutts A.D.M., Dodgshun T.J. 2007. The nature and extent of organisms in vessel sea-chests: A protected mechanism for marine bioinvasions. Marine Pollution Bulletin 54 (7): 875-886. DOI: 10.1016/j.marpolbul.2007.03.011.

Flagella M.M., Soria A., Buia M.C. 2006. Shipping traffic and introduction of non-indigenous organisms: Study case in two Italian harbours. Ocean and Coastal Management 49 (2): 947-960. DOI: 10.1016/j.ocecoaman.2006.08.009.

Froese R., Pauly D. (eds.) 2010. FishBase. [version 01/2010] http://www.fishbase.org.

Galil B.S. 2009. Taking stock: Inventory of alien species in the Mediterranean Sea. Biological Invasions 11 (2): 359-372. DOI: 10.1007/s10530-008-9253-y.

Gerhardinger L.C., Freitas M.O., Andrade A.B., Rangel C.A. 2006. Omobranchus punctatus (Teleostei: Blenniidae), an exotic blenny in the Southwestern Atlantic. Biological Invasions 8 (4): 941-946. DOI: 10.1007/s10530-005-5104-2.

Golani D., Orsi Relini L., Massutí E., Quignard J.P. 2002. CIESM Atlas of exotic species in the Mediterranean. Vol. 1. Fishes. Briand F. (ed.) CIESM Publications, Monaco.

Goren M., Gayer K., Lazarus N. 2009. First record of the Far East chameleon goby Tridentiger trigonocephalus (Gill, 1859) in the Mediterranean Sea. Aquatic Invasions 4 (2): 413-415. DOI: 10.3391/ai.2009.4.2.22.
Gregg M., Rigby G., Hallegraeff G.M. 2009. Review of two decades of progress in the development of management options for reducing or eradicating phytoplankton, zooplankton and bacteria in ship's ballast water. Aquatic Invasions 4 (3): 521-565. DOI: 10.3391/ai.2009.4.3.14.

Kim M.-J., An H.-S., Hong S.-W., Park J.-Y. 2008. Investigation of genetic diversity between wild-caught and hatchery-reared rock bream Oplegnathus fasciatus using microsatellite DNA analysis. Journal of the Fisheries Science and Technology 11 (2): 82-87. KOI: KISTI1.1003/JNL.JAKO200828837396604.

Koh J.N., Kim Y.U. 1992. Embryonic development and morphology of larvae and juveniles of parrot fish, Oplegnathus fasciatus (Temminck et Schlegel). Bulletin of National Fisheries University of Pusan (Natural Sciences) 32 (2): 29-45.

Mastrototaro F., Carlucci R., Capezzuto F., Sion L. 2007. First record of dwarf flathead Elates ransonnetii (Platycephalidae) in the Mediterranean Sea (North-West Ionian Sea). Cybium 31 (3): 393-394.

Zenetos A., Çinar M.E., Pancucci-Papadopoulou M.A., Harmelin J.G., Furnari G., Andaloro F., Bellou N., Streftaris N., Zibrowius H. 2005. Annotated list of marine alien species in the Mediterranean with records of the worst invasive species. Mediterranean Marine Science 6 (2): 63-118.

Received: 3 February 2010

Accepted: 1 April 2010

Published electronically: 15 December 2010 